\title{
Appendix B \\ Faith and Facts in James's "Will to Believe"
}

Several critics of my study of William James on the Cour-age to Believe were disturbed by what they saw as my voluntaristic interpretation of James's argument. ${ }^{1}$ So strongly had I stressed the precursive force of the "will" to believe-not merely the "right" or "willingness" or "readiness" to believe-that I ran the risk of finishing, they opined, by leaving James's pragmatism entirely out of the picture.

Moreover, my critics might be thought to have excellent reason to accuse me of seriously exacerbating this voluntaristic view of Jamesian belief in a more recent article, where I tried to prove that there was a genuine "deontological streak" running through James's ethic. That deontological element, I argued, became crucially operative to keep the "will" to believe from becoming a wanton exercise in "wishful thinking." 2 But it could also be argued that the injection of a strong dose of deontology ran the risk of making the voluntarism I read into James's views that much more voluntaristic and, consequently, that much less pragmatically obedient to evidence-to "the facts."

Let me begin by conceding that there is a good deal of merit in such contentions, and, prima facie at least, good reason to be disturbed by such a voluntaristic posture. For James's more customary appeal to pragmatic verifi-

An earlier version of this essay appeared in International Philosophical Quarterly, 35, No. 3 (September 1991), 283-99. 
cation has this much to be said for it: it is aimed at reining in our tendency toward "wishful thinking," toward believing as true whatever we want to be true-the "facts" to the contrary notwithstanding. It would seem selfevident that any conscientious thinker ought to take care to ensure that "the facts" warrant his believing that reality is as he believes it to be.

But it is important to notice that in the case before us we may be talking about "facts" of two distinct sorts, and it may be vital to keep those sorts carefully distinguished from each other. The first sort comprises the type of facts and interrelations of fact we take account of in elaborating our Weltanschauungen, our totalizing views of the universe. It is facts like these that we normally think of as deciding such issues as: whether life is worth living, whether we live in a universe that "makes sense" in moral terms, whether human actions are free or determinedand whether there exists a God Who stands as ultimate Guarantor of all the preceding. The reader familiar with James's famous lectures in popular philosophy will readily acknowledge that they testify to his burning interest in weltanschaulich questions like these-and that his focus in "The Will to Believe" is squarely on the last of those questions, concerning the theistic hypothesis.

But James also deals with another class of "facts" in these same lectures: let me call them (as I did in my study) "outcomes." Did the Alpinist succeed in vaulting over the chasm which confronted him? Or did the courageous young traveler successfully lead his fellowpassengers in an act of resistance which foiled the crooks who were resolved to rob them? In "outcome cases" like these, James thinks of the agent as possessing a robust "belief" that he can succeed in overcoming the challenge facing him. That belief he claims will be justified by a set of "future facts," represented by the successful outcome of his faith-inspired action. And if the belief is firm enough, James sometimes goes on to claim, it will "create the facts" of its own verification.

In my study of James's argument, I felt obliged first to 
criticize James's rather wholesale claim that "faith creates the facts of its own verification." ${ }^{\prime 3}$ I contended that as a universal principle that claim would not stand up to close analysis, and unnecessarily weakened the cogency of his overall position. My criticism had the obvious effect of denying that those "faith-created facts" could serve as evidential touchstones to verify pragmatically the truth of the faith in question.

But my criticism went along with the additional claim that James (and many of his loyal defenders) erred in applying the "fact-creation" thesis, which they had mistakenly drawn from "outcome cases," to that quite different class of facts involved in instances of weltanschaulich belief. This, I tried to show, was an entirely different kind of faith from the one appropriate to outcome cases. Furthermore, I argued, James should have kept it clear in his own mind and expressed it unambiguously in his prose that this was the only kind of faith to which his "will to believe" thesis could legitimately be meant to apply. ${ }^{4}$

But this weltanschaulich kind of faith, I then went on to argue, was identical with the faith that James later describes as one that does not produce verification by "produc[ing] activity creative of the fact believed," but rather, "without altering given facts," may be "a belief in an altered meaning or value for them." This shift in my argumentative focus would seem to have made my plight even more perilous: having already eliminated the entire range of "outcome facts," I have now swept the board clean of the only other kind of facts which could conceivably serve as verification of our beliefs. This would seem to leave James dangling in epistemological mid-air; hence, the obligation I now feel to bring some clarity to this troubling situation.

\section{On Faith that "Creates the Facts" OF ITS OWN VERIFICATION}

First of all, I must make clear what I do not mean to deny: if James's proposition about faith creating the facts 
of its own verification were universally true, then those "facts" would satisfy the most conscientious pragmatist's demand for experiential verification, and (contrary to my argument) no voluntaristic pressure to produce a faithassent would be appropriate. Now, James's illustrations of this claim are familiar to most readers: the Alpinist steels himself for a confident leap over a dangerous mountain chasm, or the railroad passenger acts out of the firm belief that bold action on his part will rouse his fellows to resist a band of robbers. In cases like these, James's contention would have it, the "vital heat" of strong belief will result in the success believed in. To the contrary, I objected, that confident faith may turn out to be one of several (or many) factors in the situation which could conceivably make for eventual success; but, I argued, this highly qualified truth falls well short of James's unvarnished guarantee that an ardent faith will in every case bring about that eventual success. That, I claimed, was going much too far.

But there is at least one serious objection to this contention of mine, ${ }^{6}$ and it gains considerable plausibility from the way James's epistemology is usually understood; hence, it calls for careful examination. Recall for a moment my distinction between beliefs that lead to successful "outcomes," and beliefs-or what James may have meant by the term "over-beliefs"7-of a broader, weltanschaulich kind. A belief of the former kind, I conceded, may contribute to "creating the facts" believed in: the Alpinist's belief that he can do so may contribute to his leaping successfully across the mountain chasm. But, I queried, is the same thing true of a weltanschaulich belief like the theistic hypothesis? Can our faith truly "create the facts" that verify our belief that God exists? Or (to cite those other beliefs James focuses on in this same connection) can our faith "make it so" that life is worth living, that we live in a moral universe, that our actions are free and not totally determined? My answer was, no: to speak of our beliefs creating the facts which 
would make a Weltanschauung true or untrue simply does not make sense.

\section{JAMES's “ $M+x$ " ARgument}

But, to refute that negative verdict of mine, one need look no further, apparently, than James's own heady conclusion to the familiar " $M+x$ " argument from "The Sentiment of Rationality" (Works VI, p. 84). ${ }^{8}$ There it is unmistakably clear that James did take the view about our weltanschaulich faith that "the world is good, we must say, since it is what we make it," and "The belief creates its verification." But (to repeat my original contention) these quotations, which Professor Dooley's review has drawn from James himself, represent James's brave summary of the matter in its baldest, unqualified form. ${ }^{9}$ And there is excellent reason for thinking that James came to change his mind in this regard.

Now, I cited these same quotations in my study, ${ }^{10}$ expressly calling attention to the fact that they all come from pages 81-86 of that early essay. I refer to them as representing James's "provisional conclusion" from his $\mathbf{M}+\mathrm{X}$ reasoning, argue that that conclusion will not stand up under careful analysis, and then lay stress on the fact that, in the concluding pages of that same essay, James clearly betrays his own awareness that this momentary seizure of optimism may have carried him too far. What I take to be the genuine conclusion to his essay (pp. 87-89) is couched in far more sober terms, and I, personally, am at a loss to find a single instance where James later goes back on that soberer conclusion.

To refresh the reader's mind on James's argument: "M" in his earlier equation represented "the entire world $m i$ nus the reaction of the thinker upon it" and " $x$ " the "thinker's reaction and its results." Then obviously "M + X"-standing for the "absolutely total matter of philosophic propositions" which will ultimately turn out as true of the world-will have a different value de- 
pending on how the "thinker" reacts and, by reacting, produces "results" which eventually contribute to the final composition (the "objective" $M+x$ ) of the world (p. 81). "M has its character indeterminate," James concludes some pages later, "susceptible of forming part of a thorough-going pessimism on the one hand, or of a meliorism ... on the other. All depends on the personal contribution x." "The belief" that we meliorists have that we can make the world better "creates its verification" (p. 84).

How promptly, though, will that verification come? James presents what are actually two distinct versions of his answer to that question. The first of them comes immediately on the heels of his $\mathbf{M}+\mathrm{x}$ argument, and assures us that the person who takes the world as moral and melioristic will, if the world be so in fact, "proceed to act upon [his] theory" and find it "reversed by nothing that later turns up as [his] action's fruit; it will harmonize so well with the entire drift of experience" that he will find himself in no way obliged to "change the essence of its formulation" (p. 86). His faith, in a word, will be pragmatically verified and, evidently, within the course of his life-experience.

If, on the other hand, the world be other than his theory hypothesizes, James assures us that the believer will "find himself evermore thwarted and perplexed and bemuddled by the facts of the world, and his tragic disappointment will, as experience accumulates, seem to drift farther and farther from that final atonement or reconciliation which certain partial tragedies often get"; in short, the theory will be pragmatically dis-verified by the accumulation of experienced facts which cohere more naturally with the counter-theory (p. 87).

Now, if this were James's last word on the question, the orthodox "pragmatic" interpretation would at least be accurately Jamesian: James's claim would be (rightly or wrongly) that a belief (like theism) will inevitably be verified (or falsified), confirmed, or "corrected" by subse- 
quent experience. That subsequent experience, moreover, will be experience of a reality which has been affected by the belief itself, "creating" the "facts of its own verification." Hence, the argument goes, James turns out to be definitely a pragmatist and not, as I was arguing, a voluntarist. Nor have I the right to protest that the crucial text has been drawn from a different lecture than "The Will to Believe," since it is my own professed conviction that "The Sentiment of Rationality" is enough of a companion to it that it may and must be allowed to cast its interpretive light on "The Will to Believe."

But what I have called his "provisional conclusion" is not, in fact, James's last word on the question. He has written a second version of his conclusion which, as we shall see presently, appears to have been composed some time after the first. That second conclusion begins with an admission which abruptly undermines the earlier version: "for the sake of simplicity" he admits, he has "written as if the verification might occur in the life of a single philosopher." But that, he tells us now, "is manifestly untrue." Why? Because over that short a span "the theories still face each other, and the facts of the world give countenance to both." In a "question of this scope," James now admits, we should expect that "the experience of the entire human race must make the verification, and that all the evidence will not be 'in' till the final integration of things, when the last man has had his say and contributed his share to the still unfinished $x$ " (p. 87).

And so we are faced with what I labeled a "judgmentday" type of verification which, I still hold, when it comes to "the life of a single philosopher" in his capacity as living believer, is, in strict rigor of terms, no verification at all. But even if one wished to controvert that conclusion, this much is clear: in this "second" conclusion to his essay, James has flatly denied his own earlier claim that the "verification" of his faith could come to the individual believer within the span of his own lifetime. 


\section{History OF AN EMENDATION}

I mentioned earlier that this "second conclusion" seems to have been written some time after the first one. My original reason for making that suggestion was doctrinal: the second conclusion so jars with the first as to seem, on the face of it, an afterthought consciously inserted to correct the provisional conclusion penned earlier.

But that doctrinal inference can be backed up by historical data, as well. We know that James wrote this essay in stages, revising repeatedly, deleting from and adding to the original matrix (see Works VI, pp. 326-27). The " $M$ $+\mathrm{x}$ " reasoning had already appeared in his "Quelques Considérations sur la méthode subjective," written in 1877 and published in Charles Renouvier's journal Critique Philosophique (see Works I, pp. 23-31). The same argument features in his "Rationality, Activity and Faith" which he sent to the Princeton Review as early as 1879, though it was published there only in 1882 . A letter to Charles Renouvier, written on May 8, 1882, complains about this delay in publication, but also goes on to mention that Renouvier had written about "an abstention on [James's] part to discuss certain cases of the formula $\mathrm{M}+\mathrm{x}$ \&c." James then adds that Renouvier "will observe that [James had] changed somewhat the ultra indeterministic conclusions of [his] old letter to your Journal": the communication, obviously, referred to above. His reason for those changes? "I thought I might have gone too far."

There is, obviously, matter here for informed historians of James's oeuvre to pursue; but these indications are enough to show that the $\mathrm{M}+\mathrm{x}$ argument did represent a thorn in James's side, and that he came to wonder whether he had not "gone too far" in depicting the $M$ in his equation as more "indeterminate" than was legitimate: and this was the central point in my criticism of that argument. There is, therefore, even stronger reason than I originally adduced for thinking that the "second conclusion" of "The Sentiment of Rationality" did, in fact 
represent a deliberate softening of James's earlier "provisional conclusion."

\section{A Faith Which Does Not Alter the Facts?}

James's emended version, however, contains an expression which could readily become a further bone of contention. James admits that, during the lifetime of any single philosopher, "verification" of a hypothesis like theism, for example, or of its opposite, is an impossibility. But the reason he gives for that stand-off is interesting: "the [competing] theories still face each other, and the facts of the world give countenance to both" (emphasis added).

In my original study, I linked phrases like this with others James uses to describe situations in which "the facts" themselves were incapable of grounding a decision one way or the other. ${ }^{11}$ I coupled them with that distinction which James makes explicit in a letter to Horace Kallen, written in 1907, in which he describes a kind of faith which does not produce the facts of its own verification, but "may, without altering given facts, be a belief in an altered meaning or value for them." 12 Though written some eleven years after James's famous lecture on belief, that letter showed that James had, sometime before that date, come to explicit and reflective awareness of that distinction. But I also presented the evidence ${ }^{13}$ showing that the distinction was already nibbling at the edges of his awareness in 1896, and that this semi-awareness partially accounted for the vein of pure gold that runs alongside the occasional dross marring certain passages in his earlier "popular lectures." To isolate the gold from the dross, I argued, the sympathetic critic should be willing to recast a number of passages from those earlier lectures and make them read as legitimizing the precursive intervention of the passional in the formation of our weltanschaulich "over-beliefs," 14 and only those.

For these over-beliefs, I argued, were manifestly what 
James had in mind as the instances of this second type of belief, which does not alter the "given" facts, the "facts of the world," but stage-lights them, so to speak, in such a way as to lend them a "meaning or value" different from those they suggest to the non-believer. So, for example, my coming to believe in God's existence does not eo ipso change any facts which were "given" antecedent to my act of believing; my act of faith does not of itself change the crime statistics, or make hurricanes less severe or cancers less painful: but (I take James to mean) without "altering" those given facts, my faith now enables me to view them in a certain light, from a certain perspectiveto "draw a different conclusion from them," so to speak. My faith now enables me to "live with them," and presumably even act upon them differently from the way my non-believing brother does.

Moreover, this description of a faith that does not alter the given facts obviously does not mean to deny that "believers [in Dooley's terms] can and do" go on to "create" a certain number of "facts": "for example, when they show care and concern for their fellows thereby making the world [to some extent, at least] a better place . .." (p. 572). Nor does my claim in any way imply that "choosing to believe or choosing not to believe in God changes absolutely nothing," since (the objector assumes) it condemns both believer and non-believer to be "paralytic spectators," unable to "'alter the facts in any way", (p. 574).

\section{The Stages of Belief}

An illustration may help to clarify matters. I suggest that James is thinking, in the first place, of a hypothetical person who is trying to make up his mind whether to believe that the world he lives in, say, "makes moral sense." He surveys that world, taking in as comprehensively as he can the "given facts," the "facts of the world" as they bear on the question at issue. Take the term "given" as 
(like the $M$ of James's " $M+x$ " equation) denoting the complexus of facts which that world presents, will he or nill he, for his inspection-as well as for the inspection of any comparable observer. Hypothesize for the moment that this survey is as neutral and objective as is humanly possible, since it antecedes the surveyor's taking any position, antecedes, in other words, any act of "faith" on his part which could "slant" or "weight" or "color" his view of the facts: they remain, in other words, as purely "given" as they can be, the "same" set of facts for the theist as for the atheist, for the determinist as for the libertarian, for the monist as for the pluralist. Now comes the question: what belief will our world-surveyor adopt? More pointedly, assuming that he did terminate his survey by posing some act of belief, what relationship will any act of belief he might pose bear to the "given facts"?

To this point, James's habitual answer is surprisingly negative: in weltanschaulich choices like these, "the facts practically have hardly anything to do" with what option the person will eventually make (DD 152), for "the opposing theories still face each other, and the facts of the world give countenance to both" (SR 107). This, I submit, is most plausibly what James meant by that crucial phrase in his definition of a "genuine option": the thoughtpredicament is perfectly illustrative of the kind of option "which cannot by its nature be decided on intellectual grounds" (WB 20; italics James's). If it were purely a question of which way the "given" facts point, James is saying (again!), the potential believer could never resolve his indecision one way or the other.

But, James is implying, when it comes to the kind of weltanschaulich faith we are now considering, it is never "purely" a question of which way the "given" facts point: they always point for somebody. And when the "given" facts are as irremediably ambiguous as we have supposed, the decision will, and must, depend on the decider, and on the decider's willingness to permit the "passional" to influence his decision starting from the very first move in his survey of the "facts." 
For the hypothesis of a purely "neutral" observer of purely "given" facts "of the world" is, James insistently reminds us, exactly that: a hypothetical construct. But it is a useful construct, permitting us to trace the evolution of our faith options as though they occurred in distinct phases. ${ }^{15}$ First, we have the "hypothetical" phase picturing a purely neutral observer of the "given" facts "of the world." If such an observer could exist, "the facts" would remain ineradicably ambiguous for him. In a "second" phase, we have what is always the actual reality: an observer voluntaristically "slanting" his survey of the "given" facts so that they become "the facts for him"they now "point" toward the conclusion that the passional side of his nature deems acceptable. Now comes the third phase, perhaps only rationally distinct from the second, but with a distinction that puts order into our thinking: the observer decides for the option indicated by what have now become the "facts for him." Finally, in a fourth phase, the observer, now become a believer, "acts out" his faith by "creating" a set of "world-altering" facts (call them "consequent" on his belief, like the " $x$ " of the $M+$ $\mathrm{X}$ equation) in line with what he has come to believe.

We shall see presently that James gives a number of examples which illustrate the faith-stages just described as proper to phases two and three. But my contention for the present is this: both these stages represent a faith which has "altered" the "meaning and value" which the antecedently "given" facts of the world have for the believer, without actually altering those facts themselves, and without as yet issuing into the (phase four) "faithconsequent" activities whereby the believer sets about altering the world. Now, it should be obvious that this description in no way denies that, once he has made his decision for belief, the believer may, even should, strive to "alter the facts" of our world on the basis of that belief. But the "facts" we are now talking about are no longer what James intends by the "given facts" of our world, and the fact-altering activity in question, along with the facts "created" by that activity, are consequent to belief. 


\section{Verification By “Consequent” Facts}

But an orthodox Jamesian would have every right to raise now a question which is far more relevant to James's pragmatism: can the array of "consequent facts" serve as pragmatic verification of the believer's faith? No one would seriously doubt that "believers can and do create facts" when "they show care and concern for their fellows, thereby making the world [of consequent facts] a better place." What I am questioning is whether Professor Dooley is entitled immediately to append the claim (p. 572) that this "better place" of consequent "facts . . . would verify belief in God." And it remains my conviction that that claim is neither objectively sound nor authentically Jamesian.

As to the claims's objective soundness, it seems fairly evident that while believers can (and, indeed, should) strive to alter the facts of our world, they are normally able to alter them only within certain limits. Choosing to believe in God and act on that belief may not go so far as to empower the believer to change everything he or she would long to change; and making the world a somewhat better place may not make it so good a place as to "verify belief in God" beyond all residual ambiguity. And we shall shortly see that James was lucidly aware of that residual ambiguity.

Clearly, then, both James and I were arguing for the legitimacy of belief; we were both commending belief on the shared assumption that our faith should influence our activity, and so result in some real changes, however modest, in the world about us. This was precisely the root of my difference with James L. Muyskens's contention that James would be better understood as justifying, not belief, but "hope": the hope Muyskens advocates did not seem to me the efficacious font of action that James's "strenuous mood" seems to require. ${ }^{16}$ But while it is Jamesian to insist that faith issue into consonant activity, it is far from "Jamesian" to believe that each of our individual faiths, issuing into whatever beneficent actions 
they may engender, can so change the face of the universe we live in, so alter the evidential situation confronting other potential believers, that the total ensemble of "facts" of that ameliorated universe will argue peremptorily for theism over atheism.

\section{Where the Difference Lies}

But obviously, one major pivot of my interpretation of James's lecture is the view I have espoused of James's famous " $M+x$ " argument from "The Sentiment of Rationality," complete with its corollary that the second, emended version of that argument will not sustain the twin conclusions that this world is simply "what we make of it," and "The belief [that it is good] creates its own verification" (Dooley, p. 575). ${ }^{17}$ But it should also be clear that my claim entails the refusal to treat "over-beliefs" and "outcome beliefs" along the same lines, and notably, an insistence on a uniformly factual basis for pragmatically verifying all our beliefs, including those which are weltanschaulich in nature. Perhaps the most satisfying way of resolving any remaining doubts on these issues is to find out whether the first, or the the second, "soberer," version of James's $\mathbf{M}+\mathbf{x}$ argument is endorsed in his later works. Does the later James, in other words, require (as several of my critics would contend) pragmatic verification of our weltanschaulich beliefs? We shall have to confront that issue shortly.

\section{“The Will to Believe” in James's LAter Works}

Before advancing to that question, however, I should clear the decks of another possible position: perhaps, it might be argued, I have not dealt with Professor Dooley's position at its full strength. He may not be thinking of the changes that can be wrought by an individual believer, but speculating, rather, on the possibility that as more 
and more humans act-by the thousands, the millionsin Jamesian style, the world may thereby be changed more and more for the better. In that case, "the facts" of that improved world might no longer be so ambiguous as to "give countenance to both" the opposing theories James is dealing with. Granted, that might be simply a speculative flight, but it could be illuminating to see whether there is any textual support for considering it as in any sense Jamesian.

That question brings up still another: several of my critics queried whether my entire interpretation of the relatively early "Will to Believe" would stand up to examination in the light of James's subsequent development. ${ }^{18}$ Two features of my interpretation call for particular attention: first, what happens, in James's later writings, to the sweeping claim he made in the "provisional" conclusion to his "Sentiment of Rationality" that "faith creates the facts" of its own verification? And, second, does he confirm or weaken my claim that his "will to believe" thesis legitimately applies only to weltanschaulich faiths, and that such faiths may confer a new meaning upon, but without themselves altering, the "given" facts of reality?

\section{Does Faith Create the Facts OF ITS OWN VERIFICATION?}

I have not, in the first place, been able to find any identifiable trace of the "fact-creation" claim in The Varieties of Religious Experience (1902). But in Pragmatism, written some four or five years later, James is arguing (pp. 136$37 ; 142-43$ ) for his melioristic way of understanding the proposition that the "world can be saved." For the pragmatistic thinker, he explains, the question comes down to whether or not the world's salvation is a "concretely grounded" or "well-grounded" possibility. But what does that expression mean?

First, James replies, "there are no preventive condi- 
tions present, but . . . some of the conditions of production of the possible thing actually are here." For a chicken to be "concretely possible," then, there must be no "selfcontradiction" in the idea of "chicken," no "boys, skunks, or other enemies about," and at least one "actual egg" in existence. "As the actual conditions [including 'actual egg-plus actual sitting hen, or incubator, or what not'] approach completeness the chicken becomes a better and better-grounded possibility. When the conditions are entirely complete, [actual chicken] ceases to be a possibility, and turns into an actual fact." Always, of course (the reader feels compelled to add), provided that any armies of boys or hordes of skunks can be kept out of the act!

Now, says James, apply this analysis to the (clearly weltanschaulich) question whether the "salvation of the world" is a concrete possibility. "Pragmatically" this would mean that

some of the conditions of the world's deliverance do actually exist. The more of them there are existent, and the fewer preventing conditions you can find, the bettergrounded is salvation's possibility, the more probable does the fact of the deliverance become.

This, James goes on to argue, is how his attitude of "meliorism" views the matter: it sees the world's salvation as neither impossible nor inevitable, but "treats it as a possibility, which becomes more and more of a probability the more numerous the actual conditions of salvation become" and, one is tempted once more to interject, the more whatever "preventing conditions" which may exist are overcome. For any such "ideals" to become realities, they must first be "grounded" in "live champions" such as we ourselves are; then, "if the complementary conditions come and add themselves, our ideals will become actual things." What does he mean by those "complementary conditions"? "They are, first, such a mixture of things as will in the fulness of time give us a chance, a gap that we can spring into"; let us call that the "objec- 
tive" side of the matter. From the subjective side comes the complement of that: "our act."

Now James comes to the question that concerns us here: "Does our act create the world's salvation ... not the whole world's salvation of course, but just so much of this as itself covers of the world's extent?" Boldly he asks, "Why not?" That bold queston comes down to mean, why should we not take our actions at what seems to be their face-value, as the "turning-places and growingplaces ... of the world," the only places and ways the world may grow: pace the monist whose block-universe theory insists that, rationally, the only agent of the world's growth must be "the integral world itself." But, James admits, his pluralist theory implies that "the wishes of the individual" he has supposed as crucial in the world's growth "are only one condition." There are other individuals, indeed "all sorts of resistances," in his pluralistic world, so that the world "grows . . . from compromise to compromise, only gets organized gradually" (if, in fact, his reader whispers the hope, it gets finally organized at all).

Ponder this complex, carefully hedged, and at bottom very guarded claim, where our individual wishes (and beliefs, presumably) are "only one condition" among many, and compare it with the relatively simplistic optimism of the uncorrected " $M+x$ " reasoning of "The Sentiment of Rationality," and it is plain that James has come a considerable distance.

In A Pluralistic Universe, written a year later, James ends his final lecture by explaining the "faith-ladder" which (as we shall see further on) is the route which, he claims, all thinkers follow in deciding between those two major weltanschaulich options, pluralism or monism. His hearers will undoubtedly make their personal options, he observes, on equally non-logical grounds. "And [their] acting" in accordance with the option they have made "may in certain special cases be a means of making it securely true in the end" (p. 148). Faith, expressed in actions, may, and in certain cases must, be a means: 
surely the steam has gone out of his earlier unqualified conclusion!

Some Problems of Philosophy, on which James was working the very year he died (1910), touches on the same issue in an "Appendix" entitled (significantly) "Faith and the Right to Believe" (pp. 111-13). Here he presents a series of contrasts between what he terms the "intellectualist" and the "pragmatist" views of the world. Summing up the latter, he proclaims his evolutionary belief that "work is still doing in the world-process, and that in that work we are called to bear our share." But "our share" is, manifestly, only part of the story.

Hence (I italicize the relevant terms) the provisional tenor of his conclusion: "The character of the world's results," he says, "may in part depend upon our acts. Our acts may depend on our religion,--on our notresisting our faith-tendencies, or on our sustaining them in spite of 'evidence' being incomplete." These faithtendencies, he goes on to say, are "expressions of our good-will towards certain forms of result" and are for that very reason "extremely active psychological forces, constantly out-stripping evidence" (pp. 112-13). "Extremely active" they may be, but we are given no specifics on the extent of their efficacy to "create" the "forms of result" they aim toward. The explicit admission, furthermore, that our faith tendencies are "constantly outstripping evidence" could explain why they may require "sustaining" against the doubts that could spring from that absence of verification. But while that may come down only to restating the truism that faith always remains faith, it also effectively discards as authentically Jamesian the contention that our faiths can be counted on to create the facts which remove all such "doubts," so that our faith-tendencies need no longer be "constantly outstripping the evidence."

There follows, somewhat abruptly, a description of the "faith-ladder" which the believer mounts stepwise from thinking a certain Weltanschauung might, then may, ought, must, and finally "shall be true, at any rate for 
me." No "intellectual chain of inferences," James admits, this ladder of "faith" is the expression, rather, of our "good will, our "will to believe" " that we live in a pluralistic universe "requiring the good-will and active faith, theoretical and practical, of all concerned to make it 'come true.'" "Requiring," yes: but guaranteeing that it will come true? Again, James's statement is far more measured than it once was.

His conclusion is equally measured: he ends by warning his "intellectualist" adversary that rejecting the legitimacy of such a believing attitude would "debar us from ever admitting that [pluralistic, melioristic] universe to be true." Is that quite the same, though, as assuring us, in positive terms, that adopting the will to believe will issue into verification that such a universe is "true"?

In sum, my contention on this particular issue closely resembles Smith's: ${ }^{19}$ James had every right to claim that "belief in the possibility of the outcome's having a certain character is, or may be, a factor producing the result." For in cases where "antecedent belief in the possibility of success [in leaping over a chasm, for example] affects my effort in a positive way, then I have contributed in some measure to the outcome if it is successful." Hence "the belief is 'true' about some aspects at least of the total situation in which it figured." But that guarded claim corresponds far more closely to what James wrote in his later works, and only remotely to the provisional conclusion of his earlier " $M+x$ " equation.

\section{The Two Kinds of Faith in James's Later Works}

Finally, I submit that James's later works confirm his acceptance of the kind of faith which I described as proper to phases two and three in the foregoing analysis. A faith of this sort, James tells us, "may, without altering given facts, be a belief in an altered meaning or value for them."

Perhaps the classic, and classically paradoxical, formulation of this kind of faith occurs, precisely in reference 
to the theistic hypothesis, in The Varieties of Religious Experience. On pages 202-206 James presents a number of quotations to illustrate that feature of the religious conversion experience which he describes as "the objective change the world often appears to undergo" (emphasis added). This is how he refers to that paradoxical experience when the objective world itself seems to have been endowed with a "clean and beautiful newness" which the convert had not detected there before. And yet James makes it evident throughout that the convert is nevertheless beholding the very same "objective" world of "given facts" as he did before, and as his non-converted fellow humans still behold.

Returning to the same paradox on page 373 , he explains how prayer can "temper" us into becoming more receptive to the world as it religiously is:

The outward face of nature need not alter, but the expressions of meaning in it alter. It was dead and is alive again. It is like the difference between looking on a person without love, or upon the same person with love. . . . We meet a new world when we meet the old world in the spirit which ... prayer infuses.

The parallelism with his description to Kallen of the "second kind" of faith is striking, but less surprising in that both texts are roughly contemporaneous.

But James remains substantially consistent in the years that follow: in Pragmatism (pp. 9-12), though less dramatically than in his descriptions of religious conversion, the same effect is attributed to the root "philosophy" which "determines the perspective" each of us brings to our several worlds. James makes it clear that he is not using "philosophy" in its technical meaning, but is referring to that "dumb sense," rather, of what life deeply means, "our individual way of just seeing and feeling the total push and pressure of the cosmos." That (call it a pre-reflective) "posture," that personal way of seeing, not this or that particular but everything within our ken, that "temperamental vision," gives each of us "a stronger 
bias" than any objective premises. It "loads the evidence . . . one way or the other," in favor of tough- or tendermindedness, and therefore, as succeeding lectures make clear, in favor of any one weltanschaulich option over its opposite member: in James's own case, for empiricism over rationalism, pluralism over monism, freedom over determinism, pragmatic meliorism over absolute forms of either optimism or pessimism, and so on.

Further on, James's language becomes distinctly valueladen: the opposing visions are traced to "healthy-" vs. "sick-" or "morbid-mindedness." Indeed, we all have our "moments of discouragement," and as humans can be "healthy minds one day and sick souls the next," and so, in consequence, "see" the same objective world in different terms. But, he continues, as philosophers we must frankly and consistently adopt one form of vision over the other, knowing full well that, in the end, "it is our faith and not our logic that decides such questions" (pp. 139-42). Once again it is clear from the context that both "healthy" and "morbid" minds are looking out at the very same universe. The "given facts" are the same for both of them; it is their "faith," their "temperamental vision," which decides how they "see" that identical world of facts in the most universal terms. But, in addition, James seems to suggest that being philosophical requires that one freely choose consistently to adopt one perspective over its competitor; and, one assumes, he means by this that we both should and can adopt the "healthy" rather than the "morbid" way of viewing things.

A Pluralistic Universe, from 1908, stresses that same precursive quality, but this time James speaks of all philosophers as having their personal "visions, modes of feeling the whole push, seeing the whole drift of life": he is implying, again, that our Weltanschauungen rise up from the passional part of us. But here he describes those visions as "forced on one"-not by the facts or by theoretical considerations, but-"by one's total character and experience, and on the whole preferred-there is no 
other truthful word-as one's best working attitude." Those visions, however, clearly correspond to mind-sets (or heart-sets) which James thinks are in place before the person takes on the conceptualizing and generalizing efforts (which are beyond the "primitive" mind's capacity) involved in technical philosophizing.

But does this conceptualizing effort work toward tempering, or correcting, the pre-technical vision? James's answer to that question may be unsettling, but it comes to this: once the generalizing intellect awoke, "then began those divergences of conception which all later experience seems rather to have deepened than to have effaced, because objective nature has contributed to both sides impartially, and has let the thinkers emphasize different parts of her, and pile up opposite imaginary supplements" (pp. 14-15). In this dense and somewhat tumbling sentence, I submit that "divergences of conception" clearly refers to the competing philosophic systems which have emerged from the competing pre-philosophic "visions" he has been speaking about. One might have hoped that "later experience"-a presumably common experience of "objective nature"-might gradually have "effaced" those "divergences" of conception; but it has instead, in James's view (alas?), only "deepened" them. For instead of contributing a steady stream of unambiguous evidence for one side and against the other, "objective nature has contributed to both sides impartially, and has let the thinkers emphasize different parts of her"-in accord, obviously, with the priorities implicit in their initial, pretechnical "vision." Clearly, though, James here remains thoroughly consistent with his earlier view, that diametrically opposed though their Weltanschauungen may be, their proponents nonetheless behold the very same "objective nature," the identically same world of "facts."

His closing remarks (pp. 147-48) return to the same point: he has just explained that pluralism and monism, as he conceives of them, "make pragmatically different ethical appeals"; but he must confess that, despite all his preceding theoretical arguments, his hearers will decide 
between those competing world-views "just as [their] own sense of rationality moves and inclines" them. For "One's general vision of the probable is what usually decides such alternatives." And at this point James makes a casual admission as unembarrassed as it is explicit: the mechanism he has just described corresponds to what he once "wrote of as the "will to believe."

He then goes on to illustrate how such decisions are made; he sketches, once again, but now more fully than before, what he calls his "faith-ladder": it moves from first entertaining a certain non-contradictory "conception of the world," then thinking that it "might" be true, then that it "may," then that it "is fit to be true." That fittingness passes into "it would be well if it were true, it ought to be true" until it becomes a "must be true." The ultimate conclusion is a highly personal "decision": "It shall be held for true, you decide; it shall be as if true, for you." "Not one step in this process is logical," James insists, "yet it is the way in which pluralists and monists alike espouse and hold fast to their visions." But the implication, again, is that both pluralists and monists behold the same factual world. Hence what James goes on to say can fit either party: this faith-decision "is life exceeding logic, it is the practical reason for which the theoretic reason finds arguments after the conclusion is once there" (italics mine).

\section{Conclusion: Faith and Facts}

To sum up: when asked whether a belief is validated by the evidence of "facts," James replies by bringing two sorts of facts into play. When striving to illustrate his thesis about "willing" to believe, he first proposes an array of "outcome" cases, and argues from them that faith can "create the facts" which then serve as its verification: if the Alpinist, for example, believes firmly enough that he can do it, he will succeed in vaulting the abyss which yawns at his feet. 
I have tried to show that there are at least two features about such outcome cases which preclude their answering to the needs of James's argument: first, that even in outcome cases, faith cannot be counted on to ensure success in every instance; as even James came later to recognize, there are too many other factors whose efficacy needs to be taken into account. But, second, the argument from outcome cases is irrelevant to the issue at hand, for his popular lectures, including "The Will to Believe," attest to the fact that James is really concerned with another kind of faith: he is concerned with our faith in weltanschaulich issues like the existence of God. And this, in turn, implies that he is interested in another kind of "facts." Although he attempts, in one instance and (so far as I have been able to find) one instance only (in the " $M+x$ " argument), to equate such issues with outcome issues, obviously hoping thereby to bring faith in weltanschaulich issues within reach of his pragmatic method of verification, careful attention to the chronology of his writings shows that he came to realize the vanity of that attempt: no individual philosopher can hope to verify a truly weltanschaulich belief within his own lifetime; his faith stubbornly remains exactly that, a faith.

Is there no possibility, then, of justifying our faith in weltanschaulich propositions by consulting "the facts"? Having already answered that question in the negative, James confirms his negative answer by calling attention to the crucial difference between the kind of faith which can produce activity which "alters" the facts, and another kind of faith which does not alter the facts, but lends them an altered meaning or value. A moment of reflection, along with James's own later observations, again shows that he views this latter as the kind of faith we repose in weltanschaulich propositions, like the existence of God. But, James contends, it is equally evident that "the facts themselves" are the same for both believer and unbeliever; hence, neither party can appeal to those facts for "verification" of one belief over its contradictory.

This is why James repeatedly insists, both early and 
late, that our "passional nature," our "will" to believe in one side of the argument over the other, must be allowed to settle the issue. But our inveterate sense of epistemological responsibility still protests: is this no more than a reversion to something like "wishful thinking"? Granted that what decides such questions may not be evidence swaying the intellect, but grounds which move the will, there must still be some criterion for distinguishing when those grounds are legitimate and illegitimate. Does James furnish such a criterion? No defense of his celebrated lecture can claim to be adequate unless it answers that question satisfactorily. I hope to furnish a loyal attempt at an answer to that question in Appendix C.

\section{CodA: A World Without Evil?}

One final remark about a possibility raised by James's idea of a melioristic universe. Above, I briefly alluded to the possibility that if sufficiently large numbers of human beings acted energetically on their theistic-cummelioristic belief, the world could conceivably be made so much better a place that "the facts" would eventually attest unambiguously to the rightness of that belief. I have searched for a text which would show James encouraging that notion, in vain.

There are, however, a number of texts which prompt the conviction that James would have rejected that possibility. Edward Madden refers to several of them while dealing with the nettling question of evil and its quasinecessary place in the Jamesian universe (Works VI, pp. $\mathrm{xv}$; xxv-xxvi; xxxii): it almost seems that James is convinced that "there ought to be evil . . . to make heroic action necessary" (Works VI, p. xxxii). Human freedom, James maintains, would have no pragmatic value if the "world were nothing but a lubberland of happiness already" (Works [Pr], p. 61).

James makes the same point with his fictio of the Creator proposing to mankind the style of universe they 
would legitimately prefer: his own choice falls, predictably, on a universe in which mankind would constantly have to collaborate with His activity by braving and overcoming evils (Works [Pr], pp. 136-39). Madden sums up well, if a trifle broadly: "it was inconceivable to James that anyone would resist the call to do battle in a good fight" (Works VI, p. xxvi); moreover, he seems to have felt unquestioningly that this was the permanent condition into which mankind would always be born.

His reaction to the experience of a stay at the Chautauqua Assembly is emblematic: in time he came to feel it was the very paragon of the "lubberland" of happiness, the "foretaste of what human society might be, were it all in the light, with no suffering and no dark corners." "This human drama without a villain or a pang," James sums it up, "this atrocious harmlessness of all things-I cannot abide with them." He would prefer to take his chances again "in the big outside worldly wilderness with all its sins and sufferings," for he aches for that element of "precipitousness ... of strength and strenuousness, intensity and dangers" which makes the human world the arena of "everlasting battle," and yet, for that very reason, the only cradle of (that vintage Jamesian word) "heroism" (Works X, pp. 152-53). These, James was convinced, were the essential ingredients which would forever define the human scene. Assuredly, changes, improvements can and should be made in certain aspects of that scene, but we must not "expect that they will make any genuine vital difference [italics James's] on a large scale to the lives of our descendants. . . . The solid meaning of life is always the same eternal thing," and "those philosophers are right who contend that the world is a standing thing, with no progress, no real history. The changing conditions of history touch only the surface of the show" (Works X, 166-67). ${ }^{20}$

These counsels have, at first reading, a surprisingly pessimistic ring; one is tempted to discard them as thoroughly un-Jamesian. But they only bring to its logical expression one of the man's central convictions: to be 
truly significant and rewarding, our lives must be open to the call of heroism, to the demands of the strenuous moral mood. This, he was convinced, was something that our moral universe would always require; belief in that moral universe would, accordingly, never be a question of yielding to the preponderance of evidence, even the evidence we might produce by acting loyally, and perhaps heroically, on our belief. There would always be moments when we would be challenged to leap courageously beyond the ambiguities of the evidence, and lend that evidence meaning and value through our resolute will to believe.

\section{Notes}

1. See, for instance, Patrick Dooley's review in Transactions of the C. S. Peirce Society, 21 (1985), 569-76. But a similar complaint is implicit in John J. McDermott's suggestion, in International Philosophical Quarterly, 26 (1986), 189-91, that there was a good deal more pragmatism in his lecture than I had given James credit for. Page references to both reviews appear in parentheses in my text.

2. "'The Will to Believe' and James's 'Deontological Streak" ' in Transactions of the C. S. Peirce Society, 28 (1992), 809-31, substantially reproduced above as Appendix A.

3. See above, pp. 70-83.

4. Ibid.

5. See ibid., p. 71. Dooley, 576n10, objects that a "close look" at the letter to Kallen discloses that "James did not distinguish between some beliefs which produce their verification and others which do not" but that "beliefs produce verification in two distinguishable ways, and that in some cases, verification may occur after the believer is dead." Dooley seems to be reading the letter to Kallen through the lens furnished him by the uncorrected version of James's unfortunate " $M+x$ " argument (which we shall examine shortly). This is tantamount to claiming that this kind of post mortem verification can count as "pragmatic" verification for the living believer himself, since only this latter kind of "verification" can be at issue.

6. I pass over Dooley's contention (p. 570) that I should 
have taken to heart what John Smith writes on p. 39 of his Purpose and Thought: The Meaning of Pragmatism (New Haven: Yale University Press, 1978). There Smith warns against alleging that "James confused the logical consequences of a proposition or hypothesis with the consequences of believing the proposition or hypothesis." Dooley's thrust goes doubly wide: first, because his quotation from Smith fails to sum up my objection at all accurately, and, second, Smith is not speaking here about "The Will to Believe" at all, but about faulty criticisms aimed at James's paper of 1898, "Philosophical Conceptions and Practical Results." In note 84 to the very next page of the volume in question, however, Smith does make a point à propos of "The Will to Believe": he speaks of the possible "confusion between the consequences (implications) of a doctrine, and the consequences of believing that doctrine." But, Smith goes on to admit, he does "not claim that there is nowhere in James" any instance of such a confusion! This is much more relevant to the criticism I was making in my analysis; but more on that analysis shortly.

7. Implied here is an interpretation of what James seemed to intend by the expression "over-belief" (i.e., an over-arching weltanschaulich belief). There are a number of loci where, implicitly or explicitly, James intends the term this way (Pragmatism, pp. 9-12; A Pluralistic Universe, pp. 14-15, 148; Varieties of Religious Experience, p. 405). But he seems to have veered (later on?) to using the term differently: it comes to mean a general proposition (though less universal than "belief" in the weltanschaulich sense of "The Will to Believe") whereby we use "reason" to "build out" interconnections from passional beliefs of the "Will to Believe" sort, to construct a scaffolding of generalities both dependent on, and supported by, them ( $V a-$ rieties of Religious Experience, pp. 165, 402-405). The citations for these and for all of James's works are taken the series The Works of William James, ed. Frederick Burckhardt (Cambridge: Harvard University Press, 1975-1988).

8. The following abbreviations are used for the "popular lectures" cited from that volume: WB for "The Will to Believe"; SR for "The Sentiment oî Rationality"; and DD for "The Dilemma of Determinism."

9. Dooley's argumentative tactic here is puzzling, for in quoting that same passage in his book on Pragmatism as $\mathrm{Hu}$ manism (Chicago: Nelson-Hall, 1974), p. 87, he enters several 
important qualifications: "the actions this belief promotes actually help to produce a melioristic universe," he writes, and our faith "helps to create," is "one of the factors bringing about verification" of our belief. These are saving qualifications indeed, and perfectly in line with my criticisms of James; but they raise the question why Dooley contents himself, in his review, with the flat declaration that "The belief creates its verification."

10. See above, pp. 77-80.

11. See above, pp. 81-82.

12. See above, p. 71.

13. See agove, pp. 70-71, 88-89.

14. See note 7, above. For Dooley's dismissive account of this hypothesis on James's growth in reflective awareness, see his review, p. 571.

15. Indeed, James's " $M$ " in his " $M+x$ " formula corresponds almost exactly to the "given facts," neutrally observed, which I hypothesize here.

16. See above, pp. 75-76.

17. Dooley here makes a series of pronouncements with which (given his misunderstanding of my position) he seems to fancy I would disagree: that "over-beliefs have an enormously real (and practical) impact upon our actions and the future of the world," and that "moral or immoral actions of flesh and blood human beings [settle] the world's fate." (To which I reply, "No problem"). From belief in God, he continues, "all sorts of actions naturally and spontaneously flow." (I could not agree more).

18. John J. McDermott posed this same query in his review. Notice, however, that there is a slight anomaly imbedded in this demand: if clear traces of his "early" doctrine can be found in his later works, James's basic consistency may be considered to create a certain presumption in favor of my interpretation of those earlier works; but if not, I can always claim that the later James simply changed his mind-as indeed I claim he quite demonstrably did about the validity of his famous " $M+$ x" argument.

19. Purpose, p. 61.

20. Quotations are from "What Makes a Life Significant," which James first delivered in 1898, the visit to Chautauqua having occurred in summer of 1895. See Works XII (1983), pp. 237-43. 
